\title{
Uniportal video-assisted thoracoscopic lobectomy for lung cancer
}

\author{
Dan Chen, Ming Du, Tao Yang \\ Department of Cardiothoracic Surgery, the First Affiliated Hospital of Chongqing Medical University, Chongqing 400016, China \\ Correspondence to: Ming Du. Department of Cardiothoracic Surgery, the First Affiliated Hospital of Chongqing Medical University, Chongqing \\ 400016, China. Email: ljdyt1103@sina.com.
}

\begin{abstract}
Great advances have been made in the multi-port video-assisted thoracoscopic surgery lobectomy in the recent two decades. However, only five years passed a more minimally surgery, namely uniportal video-assisted thoracoscopic lobectomy, was launched. Accumulating experience and exploration are being performed in most of the medical centres and hence we summarize the experience of uniportal video-assisted thoracoscopic lobectomy in our operation group.
\end{abstract}

Keywords: Video-assisted thoracic surgery (VATS); lobectomy; lung cancer

Submitted May 10, 2016. Accepted for publication May 17, 2016.

doi: $10.21037 /$ jtd.2016.05.58

View this article at: http://dx.doi.org/10.21037/jtd.2016.05.58

\section{Introduction}

In the recent two decades, the multi-port (2-4 ports) video-assisted thoracoscopic surgery (VATS) lobectomy (1-3) have made great progresses. Though the same longterm survival rate, VATS lobectomy is associated with more minimal surgery wound, less postoperative pain, less perioperative blood loss, less surgery time, less impaired lung function, less operative complication, quick recovery, and better quality of life when compared with traditional open surgery for lung cancer $(2,3)$. However, the more minimal invasive technique for lobectomy is always the goal of thoracic surgeons. Gonzalez firstly reported uniportal VATS for lobectomy and lymph node dissection in 2011 (4), making the VATS lobectomy to a new high level. There is only one incision in uniportal VATS and all surgery instruments enter the operative field via it. Several factors such as the interference of each instruments and limited operative range of activity make it difficult for VATS lobectomy.

Under the continuous and great endeavor of thoracic surgeons, uniportal VATS lobectomy has been widely used in the world (5-7). However, more experience and exploration about uniportal VATS surgery are still needed. Therefore, we summarize the experience of uniportal video-assisted thoracoscopic surgery lobectomy from Dec 2014 in our group.

\section{Operative techniques}

After general anesthesia, double-lumen endotracheal intubation, lateral position, and one-lung ventilation collapse, a 3-5 cm incision was performed between anterior axillary line and posterior axillary line. $3-5 \mathrm{~cm}$ incision is usually in the 4th intercostal space when upper lobectomy, and is in the fifth intercostal space while middle or lower lobectomy.

Right upper lung resection: lung fissure $\rightarrow$ the posterior right upper pulmonary branch $\rightarrow$ the right upper lobe bronchus $\rightarrow$ the anterior right upper pulmonary branch $\rightarrow$ the right superior pulmonary vein (Figure 1).

Left upper lobectomy: lung fissure $\rightarrow$ the left pulmonary segments artery $\rightarrow$ the left lung bronchus $\rightarrow$ the left pulmonary vein (Figure 2).

Left and right lower lobectomy: lung fissure $\rightarrow$ the lower pulmonary artery $\rightarrow$ the lower lung bronchus $\rightarrow$ the lower lung vein $\rightarrow$ the lower pulmonary ligament [Figure $3(\mathrm{~L})$, Figure $4(\mathrm{R})]$.

Lymph node dissection [Figure 5 (2R, 4R), Figure 6 $(5 \mathrm{~L}, 6 \mathrm{~L})$, Figure $7(7 \mathrm{~L})$, Figure $8(7 \mathrm{R})] \rightarrow$ thoracic drainage catheter tube $\rightarrow$ and then suture. 


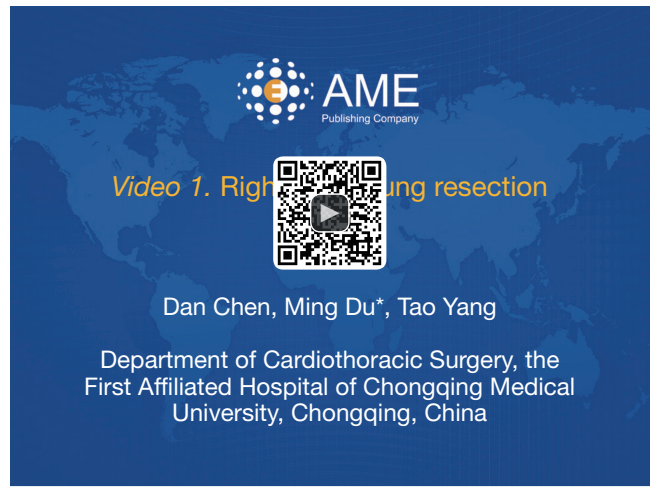

Figure 1 Right upper lung resection (8).

Available online: http://www.asvide.com/articles/1025

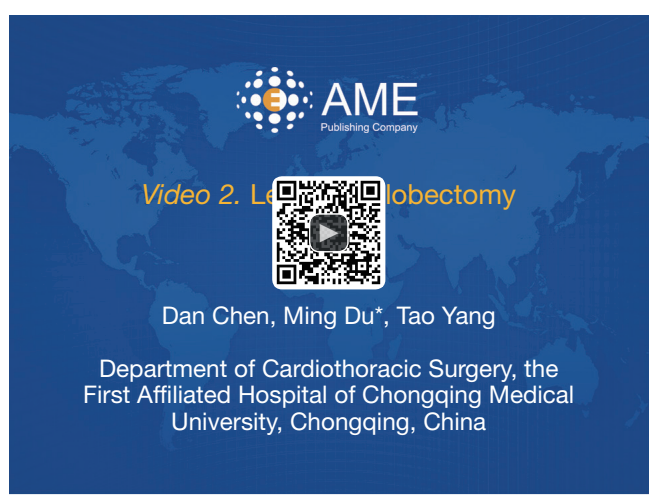

Figure 2 Left upper lobectomy (9).

Available online: http://www.asvide.com/articles/1026

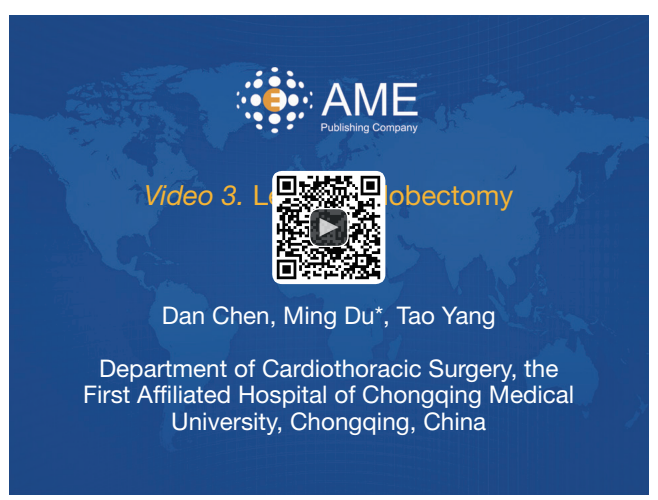

Figure 3 Left lower lobectomy (10).

Available online: http://www.asvide.com/articles/1027

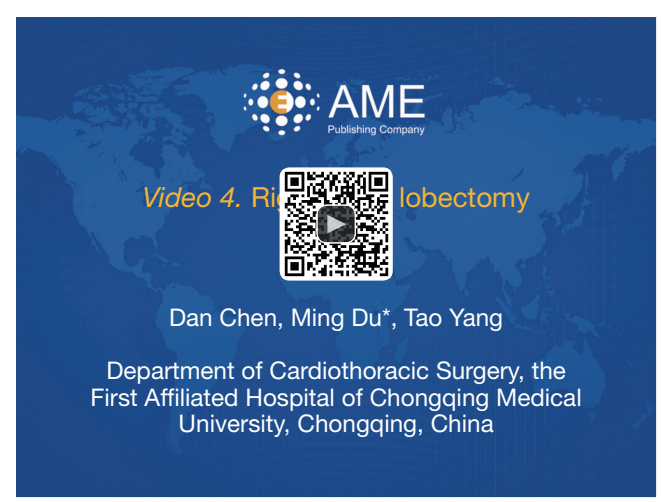

Figure 4 Right lower lobectomy (11).

Available online: http://www.asvide.com/articles/1028

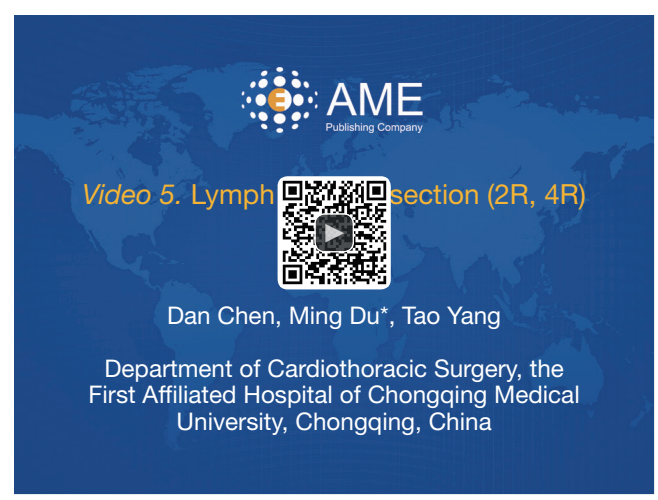

Figure 5 Lymph node dissection (2R, 4R) (12).

Available online: http://www.asvide.com/articles/1029

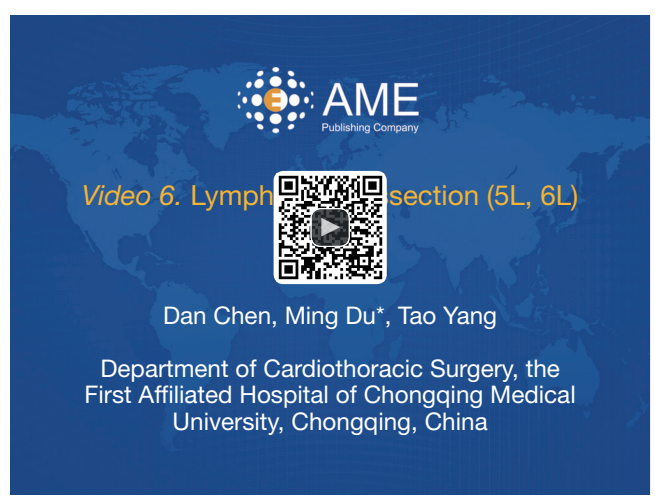

Figure 6 Lymph node dissection (5L, 6L) (13).

Available online: http://www.asvide.com/articles/1030 


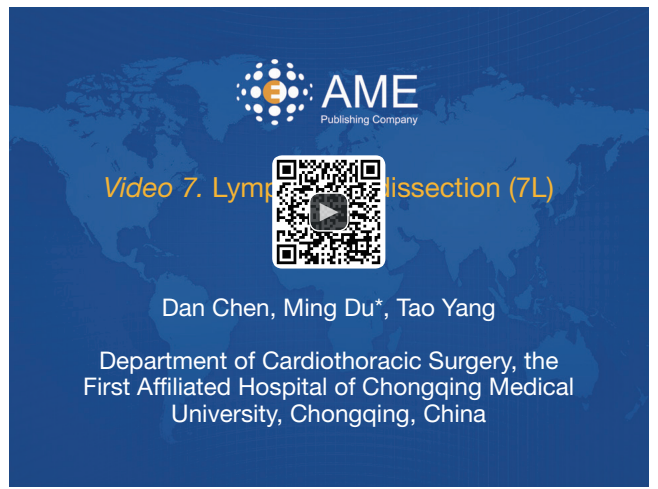

Figure 7 Lymph node dissection (7L) (14).

Available online: http://www.asvide.com/articles/1031

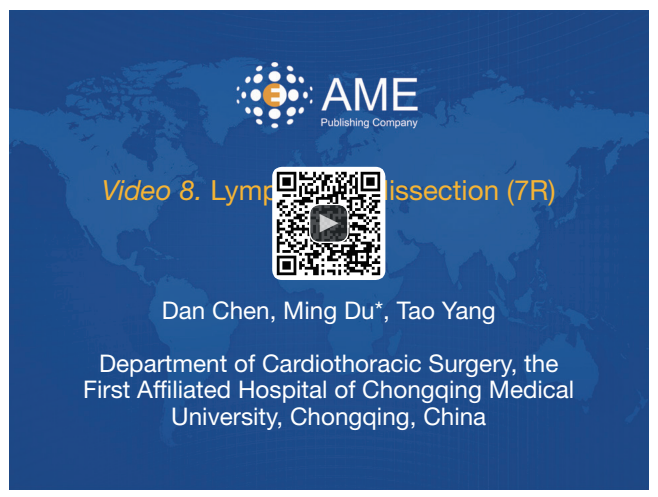

Figure 8 Lymph node dissection (7R) (15).

Available online: http://www.asvide.com/articles/1032

\section{Comments}

Compared with multi-port VATS lobectomy, uniportal VATS lobectomy could decrease the chest injury, postoperative pain, and postoperative paresthesia (16-18). In our surgery process, the thoracoscope was in the behind and the surgery instruments in the front of the port, decreasing the interference of surgery instruments and making it convenient to observe and operate.

Because the incision was forward, processing vessels or bronchus with the linear stapler was interfered by tissues behind the target organ, making the thoracoscopic lobectomy a difficulty. In our surgery process, lung resection substantially was start from back to front for upper lung lobe and middle lobe and from top to bottom for the lower lung lobe. This procedure solved the problem, reduced the difficulty of the surgery, and increased the reproducibility of this method. In summary, the similar perioperative clinical outcomes could be found in multi-port VATS and uniportal VATS lobectomy (19).

\section{Conclusions}

Uniportal VATS lobectomy is believed to be safe, feasible and easily replicable.

\section{Acknowledgements}

None.

\section{Footnote}

Conflicts of Interest: The authors have no conflicts of interest to declare.

\section{References}

1. Rocco G, Internullo E, Cassivi SD, et al. The variability of practice in minimally invasive thoracic surgery for pulmonary resections. Thorac Surg Clin 2008;18:235-47.

2. Whitson BA, Groth SS, Duval SJ, et al. Surgery for earlystage non-small cell lung cancer: a systematic review of the video-assisted thoracoscopic surgery versus thoracotomy approaches to lobectomy. Ann Thorac Surg 2008;86:200816; discussion 2016-8.

3. Yan TD, Black D, Bannon PG, et al. Systematic review and meta-analysis of randomized and nonrandomized trials on safety and efficacy of video-assisted thoracic surgery lobectomy for early-stage non-small-cell lung cancer. J Clin Oncol 2009;27:2553-62.

4. Gonzalez D, Paradela M, Garcia J, et al. Single-port videoassisted thoracoscopic lobectomy. Interact Cardiovasc Thorac Surg 2011;12:514-5.

5. Tam JK, Lim KS. Total muscle-sparing uniportal videoassisted thoracoscopic surgery lobectomy. Ann Thorac Surg 2013;96:1982-6.

6. Liu CY, Lin CS, Shih CH, et al. Single-port video-assisted thoracoscopic surgery for lung cancer. J Thorac Dis 2014;6:14-21.

7. Gonzalez-Rivas D, Fieira E, Delgado M, et al. Uniportal video-assisted thoracoscopic lobectomy. J Thorac Dis 2013;5:S234-45.

8. Chen D, Du M, Yang T. Right upper lung resection. Asvide 2016;3:263. Available online: http://www.asvide. com/articles/1025 
9. Chen D, Du M, Yang T. Left upper lobectomy. Asvide 2016;3:264. Available online: http://www.asvide.com/ articles/1026

10. Chen D, Du M, Yang T. Left lower lobectomy. Asvide 2016;3:265. Available online: http://www.asvide.com/ articles/1027

11. Chen D, Du M, Yang T. Right lower lobectomy. Asvide 2016;3:266. Available online: http://www.asvide.com/ articles/1028

12. Chen D, Du M, Yang T. Lymph node dissection (2R, 4R). Asvide 2016;3:267. Available online: http://www.asvide. com/articles/1029

13. Chen D, Du M, Yang T. Lymph node dissection (5L, 6L). Asvide 2016;3:268. Available online: http://www.asvide. com/articles/1030

14. Chen D, Du M, Yang T. Lymph node dissection (7L). Asvide 2016;3:269. Available online: http://www.asvide. com/articles/1031

15. Chen D, Du M, Yang T. Lymph node dissection (7R).

Cite this article as: Chen D, Du M, Yang T. Uniportal videoassisted thoracoscopic lobectomy for lung cancer. J Thorac Dis 2016;8(7):1830-1833. doi: 10.21037/jtd.2016.05.58
Asvide 2016;3:270. Available online: http://www.asvide. com/articles/1032

16. Tamura M, Shimizu Y, Hashizume Y. et al. Pain following thoracoscopic surgery: retrospective analysis between single-incision and three-port video-assisted thoracoscopic surgery. J Cardiothorac Surg 2013;8:153.

17. Salati M, Brunelli A, Rocco G. Uniportal video-assisted thoracic surgery for diagnosis and treatment of intrathoracic conditions. Thorac Surg Clin 2008;18:305-10.

18. Jutley RS, Khalil MW, Rocco G. Uniportal vs standard three-port VATS technique for spontaneous pneumothorax: comparison of post-operative pain and residual paraesthesia. Eur J Cardiothorac Surg 2005;28:43-6.

19. Wang BY, Liu CY, Hsu PK, et al. Single-incision versus multiple-incision thoracoscopic lobectomy and segmentectomy: a propensity-matched analysis. Ann Surg 2015;261:793-9. 